\title{
Campaigner, watchdog or municipal lackey? Reflections on the inter- war provincial press, local identity and civic welfarism
}

Was the inter-war period a 'golden age' for the local evening newspaper ${ }^{1}$ - the manifestation of an earlier industrialisation of the press that permitted the growth of independent journalism and the expansion of a critical Fourth Estate — addressing a wider audience at a lower price $?^{2}$ Relying on regular daily sales and advertising revenues, rather than political partisanship and party subsidies, made local evening papers genuinely 'popular': more so than their morning stablemates. ${ }^{3}$ Yet the corporate coupling of the expanding national daily and local evening presses also suggests the latter is better contextualised within the wider 'revolution' in newspaper publishing (associated with Northcliffe, and the construction of a Fleet Street-led undifferentiated 'mass'

readership). ${ }^{4}$ As such, it was implicated in the corruption of any 'free press' ideal, the suppression rather than promotion of pluralism, and the drift to tabloidisation. ${ }^{5}$ Here commercialisation turned local newspapers from being popular educators and public watchdogs into 'big business': where owners' market interests were paramount - not least during the 1920s when submitting to 'the temptations of monopoly' seemed particularly prevalent. ${ }^{6}$

Yet, ironically, as attention was drawn to the accelerated 'decline' of the evening press after 1945, with its further incorporation within an essentially single, consumerdriven commercialised newspaper industry, the 'local rag' has now been allowed an earlier, more positive role in local democratic processes. ${ }^{7}$ This article posits that the 
1920s 'commercialised' local press offered the ubiquitous civic voice; vital yet distanced from partisanship, or the reputed banality, of former or later years. It takes as its testing ground civic policy formation in public housing, examining the press's impact as a purveyor and mediator of civic constructs of progressiveness and improvement. For the inter-war period offered nominally an enabling 'golden age' interface for civic government, too; where new responsibilities for social provision were being actively

transferred by Westminster to local authorities. ${ }^{8}$ Increased social intervention brokered new local relationships, in which civic identity through active citizenship was increasingly structured in terms of the willingness of municipalities to incur debt through, amongst other things, urban renewal programmes. ${ }^{9}$ Frequently the local state was the major enactor of welfare initiatives in default of central activity; while, politically, key 'autonomous' local characteristics remained intact, publicly flagging a council's 'major and identifiable' role within the community. ${ }^{10}$ Yet at a time when journalists were also laying claim to greater professional autonomy based on the construction and reflection of a more pluralistic world, the corporatisation of the press worked to disperse, rather than concentrate, local power. Such a social confluence enabled 'editorial vigor': making it and the local press a defining force of, and in, the local community. ${ }^{11}$

\section{Structural/Functional Change and 'Legitimacy'}

In 1921 there were 89 provincial evening newspapers in England. Published in virtually every significant city and town, these offered a tangible representation of the expansion of daily newspaper buying among the lower-middle and working classes, having a combined circulation of about 4.5 million, or only 1 million fewer than all the London 
morning papers sold across Britain. ${ }^{12}$ The evening newspaper primarily addressed the material and cultural concerns of the local communities in which they circulated. Whereas local morning titles were as much 'viewspapers' as newspapers, presenting a partisan slant on national and international events in addition to local issues, the evening newspapers offered a more 'mundane' daily diet of football, horse racing results, crime, local court cases and 'snap news'. Yet, in attracting large amounts of classified advertising associated with the local economy, they were also highly profitable. ${ }^{13}$ The most successful Fleet Street daily papers, the new 'popular' press of the Daily Mail, Daily Express and Daily Herald, increased their overall readerships by 40 percent during the $1920 \mathrm{~s} .{ }^{14}$ But whereas the number of provincial morning newspapers fell by a quarter in this period, the evening titles were affected far less. Only about seven ceased publication, and total circulations may not have fallen at all. ${ }^{15}$ As such they offered a strategic obstacle to the comprehensive dominance of the London morning press in British newspaper publishing. ${ }^{16}$

In fact, the rise of Fleet Street did not signal the 'eclipse' of the provincial press, although this view had tended to predominate. ${ }^{17}$ Rather, the national daily press sought to incorporate evening papers. Titles were taken over and rationalised. In 1921 some 8 per cent of evening titles were chain owned; by 1934, the figure was at least 40 per cent. ${ }^{18}$ One consequence was the establishment of local monopolies, as the chains carved up the evening press. To many contemporaries it appeared that the local press as a political 'machine', which at least reproduced the competitive two-party system, was being supplanted by a commercial one in which alternative voices were simply eliminated in the interests of business. ${ }^{19}$ Yet Fleet Street was not particularly concerned 
about printing news from the 'parish pump'. ${ }^{20}$ By the early 1930s a form of amicable corporate co-existence had evolved, with many households taking both a Fleet Street daily and the local evening paper. ${ }^{21}$ As the Fleet Street press increasingly co-opted an expanding bourgeois consumerism for its own commercial (and political) ends, ${ }^{22}$ the local press was left freer to address the 'common good' by embracing consensually 'the community at large'. ${ }^{23}$

This 'material existence' of the commercialised press was thought likely to lead to the 'tainting' of the news, the suppression of alternative views and unfair representation. 'Editor and business manager should march hand in hand', the proprietor and editor of the Manchester Guardian, C.P. Scott allowed; but, he insisted, 'the first, be it well understood, just an inch or two in advance'. ${ }^{24}$ In practice, 'editorial sovereignty' proved to be elusive. ${ }^{25}$ Corporatisation was an inducement to 'advertisement-courting, dividendseeking, circulation-mongers' to maximise profits through forms of popularism which marginalised diversity of opinion. ${ }^{26}$ Yet, paradoxically, the business of newspapers was underpinned by beliefs in the essential function of the press as a Fourth Estate 'watchdog', working to serve an over-riding 'public interest' as an integral part of democracy. ${ }^{27}$ The chief mechanism for articulating this ideal with expressions of 'popular legitimacy' was one of professionalising journalism. Owners, managers and working journalists, too, identified and promoted an ideology and methodology of 'the public's right to know'. ${ }^{28}$ Above all, this was a journalism of disclosure, serving the public by purporting to publish 'all the news that's fit to print', even where that meant discomfiting local élites. ${ }^{29}$ This principal of objectivity, allied to techniques such as the closer sourcing of material, the greater use of first-hand news gathering, investigation and 
interviewing, and the elevation of 'facts' over comment, marked out a more visible space in the press for the work-a-day reporter. ${ }^{30}$ Moreover, the journalist's 'story' became a (sometimes, it seemed, the) defining characteristic of the newspaper. ${ }^{31}$ This 'democracy of print' existed, albeit uneasily, alongside 'market forces', so that local newspapers were driven only partly by commercial exigencies to seek wider popularity. ${ }^{32}$

It seems overly pessimistic, then, to argue that at this moment of the institutionalisation of 'the daily', newspaper journalism simply failed to resist the intrusion of commercialisation, and that political control of newspapers gave way to a form of normative licensing by advertisers. ${ }^{33}$ Local newspapers relied on the colourful presentation of 'the whole of life' to attract and keep readers: a 'newspaper had to be worth buying. ${ }^{34}$ A key to their success was the establishment of the newspaper as a routine household purchase, integral to the experience of daily life and, more occasionally, the expression of wider civic duty. This was, in many respects, a joint venture of capital, politics and journalism. ${ }^{35}$

Local newspapers functioned interactively to supply political, economic and social information: participating in the distribution of goods and services; yet also, spatially, formalising a sense of community and offering opportunities for debate. In short, they presumed to act simultaneously as scrutineers, interpreters, arbiters, social integrators, businesses and entertainers. ${ }^{36}$ The local press established its specific legitimacy through its patterns of distribution (circulating within a defined area), its location within the economy (drawing revenues from local sales, subscriptions and advertising, and promoting other local commerce), its content (locally relevant news and information), the cross-radial access it afforded the local populace, and its 'licence' (its localised 
ownership, operation and control). ${ }^{37}$ Journalists bore responsibility primarily for the information and debate functions; but also contributed incidentally to the paper's nominal responsibility to promote community cohesion as a 'public good', uncluttered by commercial imperatives. There was, too, an 'assumption of editorial power' presiding within the newspaper on the basis of selecting 'the correct news' (that, for example, which was largely socially consensual and civicly reinforcing). ${ }^{38}$

Thus in the 1920s the local press was essentially dysfunctional. Chain ownership and corporate management diluted local 'licence', while commercial concerns and residual partisanship impinged on editorial judgement. At the same time, an editoriallydriven focus on the 'parish pump' - as the principle manifestation of the local public sphere - persisted beyond the inter-war era, mitigating cruder commercial imperatives. ${ }^{39}$ Here local evening papers construed the public principally as socially and culturally complex readerships (that is, generators equally of 'public opinion' and advertising revenue), and what readers found interesting was given an importance alongside the older, alternative political notions of 'interest' ${ }^{40}$ It should not be assumed that evening newspapers regarded their chief function in the mid-1920s as 'selling information' to the exclusion of 'activating the public to become more involved with public life through discourse. ${ }^{41}$

The combining of commerce, politics and journalism was meant to circulate ideas, so that the press became a 'moral means' for change. ${ }^{42}$ Readers could bolster editorial independence, making a newspaper both financially and editorially successful. Yet while newspapers were widely assumed to be 'agents of enormous potential power', they also had to strive to achieve a level of popularity by carefully balancing their own interests 
with the attention they paid to 'the positive enjoyments of urban culture' among their readerships. ${ }^{43}$ Drawing strength from their own relatively independent assessment of their readers and their views, newspapers as local institutions became cocooned, to degrees, from the pressures exerted by civic élites and commerce. ${ }^{44}$ In the 1920 s there was much debate over the relationship between the press and the formation and expression of public opinion. ${ }^{45}$ The older, declining 'class' newspapers retained and even enhanced their partisanship with regard to civic politics. ${ }^{46}$ The newer evening press was less secure in its commercial and quasi-professional roles, however. It could make few claims for being popular in the sense of 'being for the people'; but it did not yet define "'popular" in purely market terms'. It occupied an intermediate space somewhere between the two; and, as Raymond Williams pointed out, the transformation from one kind of popularity to another cannot be taken as having been inevitable. ${ }^{47}$

\section{Theory as Practice}

On the 30 September 1925 the Leicester Mercury noted Herbert Hallam's dissatisfaction with its lead story that previous evening — 'Another Disappointment for Homeless. Housing Committee's Failure' — a disparaging commentary on the decision to exclude from the council's housing register all who had neither served in the forces nor lived in Leicester before the war. ${ }^{48}$ Hallam was especially annoyed by the suggestion that working-class families had been 'waiting in vain' because of council ineptitude. The newspaper was simply 'trying to make capital out of a totally incorrect interpretation' of his committee's proposals, he complained. The editorial response was unsympathetic: the councillor 
ought to be quite used to adverse criticism by this time in view of fact that thousands of people are looking for houses seven years after the Armistice. His view is that newspapers should ask for explanations before publishing the results of their own observations.... More that once Councillor Hallam has been approached by the "Mercury" in regard to housing matters, only to be met with the response that if he had anything to say it would be given at a later moment. That moment seldom arrives.

Such, too often, are the methods of the Housing Committee.... If it were left to the chairman to make statements in his own good time it is probable that the public would be very much more in the dark than it is at present. With the very natural dissatisfaction prevailing, it is more than time full and adequate explanations were forthcoming, explanations covering the whole ground, and showing signs of a different spirit. If such a desirable effect is achieved there will be ample cause for having aroused the ire of the chairman of Leicester's Housing Committee. ${ }^{49}$

That same day Hallam also crossed swords with the city's Mayor through the columns of the Mercury. Simpson was particularly critical of the decision to construct concrete rather than brick houses because of shortages of traditional materials and skilled labour. Five hundred of these 'Henry Boot' houses were already under construction, and an order for a further 1000 was pending, as he weighed into the debate: 'not at all impressed with the class of house that was going up', labelling the scheme a 'white elephant' and urging a dramatic reversal in corporation policy.

How should we construe these three 'simple' public exchanges within the local polity as mediated through Leicester's largest selling newspaper? Contextually, we need to note that numbers on the housing waiting list in Leicester, as elsewhere, were rising relentlessly (having tripled to around 6,000 applicants from 1920), but that until relatively 
recently few corporation houses had been built in the city. There was, therefore, a generated public perception of crisis within Leicester. ${ }^{50}$ In this light a reading geared to party political advantage offers insight. If the provincial press had little influence on national affairs by the inter-war period, all the parties — including Labour nevertheless thought that local press partisanship was essential in building or restoring political fortunes on the ground. ${ }^{51}$ In Leicester, as in many other cities, the Conservative and Liberal parties operated a loose anti-socialist alliance actively buttressed by a commercial but nonetheless party-bespoke press. ${ }^{52}$ While the intensity and authority of such pacts fluctuated markedly year by year, in pre-election periods local press partisanship intensified so that anti-socialist rhetoric particularly became vitriolic. Interpreted thus: the Leicester Mercury offered a Liberal voice in city affairs; Simpson was a Conservative (an ally, therefore, in the battle against socialism); and Hallam was a Labour nominee (explicitly a threat to 'old order' hegemony on the council, and implicitly a 'stealer' of Liberal working-class allegiances). ${ }^{53}$ That the Mercury briefly recorded Hallam's dissent, therefore, was less a signifier of balanced reporting, and more an entrée for a powerful, politically-malevolent rebuttal.

Indeed editorial and feature criticism of Hallam and the housing committee was relatively commonplace within an ongoing campaign of eighteen months standing for greater municipal provision. On several earlier occasions the Mercury had demanded Hallam's resignation: he was 'so much of an [Socialist] idealist' that he was 'unable to grasp the urgent practical needs of the day.' In its rabid partisanship the Conservative Leicester Mail, the city's other evening newspaper, was still more reminiscent of a nineteenth century provincial press (driven by its polarised support for one of the 
established parties): but now, instead, the Mail was consistently hostile to all things Labour (the party, trade unions). Its narrative was openly personalised: it was simply 'Councillor Hallam's Great Housing Failure'. Condemnation of the Housing Committee —which drew councillors from all three parties — was bypassed and instead Hallam's 'gentlemanly Socialist' nature co-opted as a political tool to dismember his manliness. His 'good intentions' and affability signified weakness: 'He will talk ... for years - with a quiet dignity which pleases and soothes, and satisfied, but does nothing.... Quite frankly he is not man enough for this big housing job. The City does not want a talker; it wants a builder. It wants a Mussolini who will get on with the job. ${ }^{54}$

Yet a focus on discord partially misreads internal and external constructions of civic affairs. Inside the chamber a 'resistance to socialism' did not preclude the sharing of positions of political patronage with Labour opponents: witness Hallam's chairmanship of the housing committee. The informal conventions of patronage-sharing, drawn from a largely 'invented' apolitical tradition of 'old party' bipartisanship, were further cemented by the committee system of decision-making, which prior to 1945 particularly engendered cross-party centric loyalties. ${ }^{55}$ Such accommodations and conventions encouraged a public discourse stressing inter-party 'fair play', and 'city before party' government through civic office - even occasionally from the Leicester Mail! ${ }^{56}$ This married well with a twentieth century tendency for provincial newspapers increasingly to 'accentuate the positive' in their constructs of 'localness' and 'civicness'. ${ }^{57}$ Doubts remain as to the scrutineering capacity of this press. Recent studies presume it to have been largely 'quiescent' or deferentially 'dull' and 'parochial', rather than inquisitorial as a function of any 'full-blooded' partisanship. ${ }^{58}$ For the press, it has been argued, 
'circumspect neutrality' 'probably' offered commercially safer avenues to maximising market share: so that, for example, as the Labour vote rose during the 1920s, so an overtly political provincial press drew its 'last breath'. ${ }^{59}$

This, however, is to understand readership fidelity in largely party partisan — that is reductionist — terms: a questionable correlative, even ignoring the propensity to antiLabour partisanship evident in papers like the Leicester Mail..$^{60}$ It is also to construe neutrality as passivity, rather than offering consensus and civic inclusivity as a purposeful dynamic spurring the development of an expanding service provision through the local state. ${ }^{61}$ To return briefly to our testing site, a consensus viewed through a passivelyorientated municipal filter might capture Hallam's brief criticism, but it ignores the authority of an editorial in full magisterial voice, fulfilling its obligations as civic 'watchdog'. Central to the criticism levelled at Hallam was that he failed to acquiesce to these inclusive 'rules of the game': his secrecy made reporting more difficult, and the committee's actions, in being less open to scrutiny, less democratic and responsive to the community's urgent needs. ${ }^{62}$ Of course there were good reasons, politically, why Hallam might choose not to interact freely with a hostile press. Yet, if a strong expectation of external scrutiny existed, or was reinvented by the press itself, newspapers had a capacity to generate considerable disquiet under the self-serving pretext of the public's right to know. ${ }^{63}$ Hints of 'vagueness' and a remote 'separateness' — of keeping the facts from the public - were constant themes of local coverage as the message of crisis was unfolded just at a time when the corporation's obligations as a provider of social housing were also being projected as pivotal. 
In any reporting system, politicians and the local press remained mutually codependent for publicity and information. Not that this relationship was unproblematic. Even in the inter-war period, when civic affairs were afforded fulsome copy by later standards, politicians disparaged the 'drastically summarized reports which appear in the local press ${ }^{64}{ }^{64}$ Similarly the 'dislike of matters being raised' independently in the press remained widespread amongst councillors. ${ }^{65}$ Nevertheless, this linkage has largely been construed in terms of elite reinforcement: where the press blandly interpret a local 'community' via its institutional structures, uncritically through the discourse of its social leaders, and reportage anyway 'celebrates' the values of order and stability.

Contradictory behaviour is explained away through a principle of exceptionality: that under certain circumstances, journalists or editors adhere to a professional code of 'public interest' in their pursuit of a good story. ${ }^{66}$

Drawing on the evidence so far presented, there are immediate shortcomings to such an analysis if applied to the 1920s. Politically, the local 'establishment' - that which supplied the 'official' news — was in flux: a transitional state apparent in the physical changes in personnel and party, but also through the contradictory discourses circulating simultaneously through local newspapers of the 'new' apoliticism, in all its inclusive guises, and a cruder anti-Labour partisanship that sought to exclude. Hallam's own erratic relationship with the press offers an exemplar of this disparity. Match, for example, the already noted personalised criticism with this front page Mercury lead 'Leicester's Busiest Man Today' — of the month previous. 
of detail in connection with the City's latest housing scheme. Councillor Hallam promised the City Council at last week's meeting that he would work through the vacation so as to be able to present tenders for the erection of a thousand houses on the Saffron-Lane estate, and he has been as good as his word. ${ }^{67}$

How should such incongruous commentaries be deconstructed? The Liberal Mercury, at least, drew an albeit 'flexible' line between party function and civic service: Hallam as a socialist attracted disproportional criticism; but as a progressive, in harness promoting the city's interest, he offers local readers 'good news'. Indeed, in the contrived format of this front page 'interview', the Mercury and Hallam are jointly applauded: neither is relaxing, neither takes a holiday; instead both place 'community welfare' first. As the Mercury later recorded, 'Councillor Hallam, and members of his committee, had come in for a great deal of criticism' for 'moving very slowly in endeavouring to stay the housing famine.' It then proceeded to 'modify this expression', arguing that 'by dint of sheer hard work', and 'consideration of every possible scheme' the Committee had made significant progress. Hallam was credited with having done much of the 'spadework', and significantly it was thought fitting that Leicester, or at least the Mercury, publicly acknowledge his achievement. ${ }^{68}$

Even the 'virulently anti-socialist' local press did, on occasion, defer positively to such 'progressive' achievements in welfare provision. ${ }^{69}$ The neighbouring Liberal Nottingham Journal (a morning daily founded by the party and the millionaire chemist Jesse Boot in 1918 to bolster the local cause) ${ }^{70}$ went further, commending Labour's electoral success in the first post-war municipal elections as providing a tonic to the previous lacklustre approach to social provision by Liberal and Conservative councillors. 
'Inaction is stagnation, and consequent ill-health', it claimed. 'Possibly the successful onslaught which Labour has made on the old regime may be the best thing', as it cited a litany of past shortcomings where profit and low rates were placed before civic provision in municipal enterprises. ${ }^{71}$ Editorially, the paper continued to take this 'progressive' line: chiding local Conservatives as 'reactionaries' and 'diehards', as it sought an identifiably independent Liberal position. $^{72}$

Flagging municipal intervention as a 'signpost' of separate identity from Conservatism ran counter to the preferred line of many Liberal councillors and aldermen, who chose publicly instead to stress their 'anti-expenditure/anti-socialist' credentials: ${ }^{73}$ clearly several tactical and ideological interpretations of civicness and even progressivism existed simultaneously. Moreover, even for a party-bespoke press, promoting other considerations increasingly grew in importance: for example, as noted already, maximising revenue or community/press legitimacy. Journalists traditionally took an 'evangelical' pride in civic achievement represented as progress; indeed, being generally local themselves, they filtered campaigning or partisan narrative through a code of a 'responsibility' to their community. ${ }^{74}$ It would be unwise to dismiss this as lacking local 'authority' because of its tendency to banal insularity, rather than to a self-idealised journalistic code of inquisitorial reporting. Nevertheless, a press devotion to promoting the 'good of the town' begs contextual questions of which community interests are being privileged and why: for those reasons of partisanship, institutional reinforcement, etc., already discussed, or, more innocuously, as a commercial function, perhaps, of civic betterment in raising community consciousness - that is making their readers, and perhaps journalists too, feel more positively about themselves. 
Yet a positive construction of 'the local', even within a progressive idiom, was not simply the preserve of particular local Liberal or Labour councillors and its press. In nearby Nottingham, William Crane - the Conservative Chair of Housing - proofed his progressive credentials not simply through his tenacious support for municipal housing but also through his discursive dismissal of fellow councillors: too many were 'reactionaries', he judged. ${ }^{75}$ In the municipally enabling climate of the 1920 s, and as numbers on the waiting list rose, even the Leicester Mail encouraged the building of low cost housing for rent, accepting that the rates would rise as a consequence. The Conservative supporting Nottingham Guardian was more fulsome in its praise of municipal housing enterprise, although it retained, too, a preference for an alternative 'public good', where houses built by the corporation were sold not let. ${ }^{76}$ Both also championed private enterprise provision as a more efficient, economical option. A shared civic identity and environmental familiarity, as one might expect, did not preclude differing narratives on 'what's best and what's needed'; nevertheless, for cities that strove to 'talk about themselves' as progressive or modern, positive agreement existed that locally initiated municipal intervention and social provision was appropriate and necessary (even if its exact scale and format remained contentious). ${ }^{77}$ Within this construct, the press's predisposition to a 'progressive civic pluralism' — for whatever reason - varied inversely to its traditional ties to overt partisanship. Even at the height of its housing campaign, the Mercury dutifully carried mayoral criticisms in several editions against its own policies. ${ }^{78}$ But the paper also marked politicians, irrespective of party, according to each's attitude as an enabler of reform. ${ }^{79}$ 
Through such discourse, while many local communities existed physically, significantly fewer were 'imagined' through a 'socially inclusive' local daily press and its continuous 'internal' dialogues about locale, which acted as a 'focus' for the 'daily life' of citizens. ${ }^{80}$ Moreover, for local newspapers, community and readership were not just coterminous, but synonymous; for local politicians, the 'perception of social reality ... frequently shaped both the form and the content of the politics they advocated'; while readers simply wanted more local news. ${ }^{81}$ It has been claimed that the capacity of the local press to mislead or misinterpret remained severely curtailed by 'local knowledge, ${ }^{82}$ Perhaps this was true of what we might loosely label 'the distinctly personal' (that primary - albeit formative — information acquired by face-to-face experience). Outside this 'private' experience, however, in 1920s provincial Britain local newspapers remained the principal channel for all 'indirect' — that is most — information. The press seldom reproduced for its 'community' the technical intricacies of proposals or counterproposals; indeed it was more prone to 'inventing' traditions, myths and images and other 'good' news. ${ }^{83}$ Nonetheless, or perhaps because of this, it retained the capacity to mould civic discourse and influence local decision-making. If 'good' news was the norm, then 'bad' news shone more brightly to disturb the status quo. The key question remains why, and how, the press might choose to do this?

\section{The Mercury campaign}

The 1920s have been portrayed as the high point of a popular idealism linking civic welfare reform to the promotion of community identity and active citizenship. ${ }^{84}$ It is 
argued, too, that at the practical interface between 'everyday' community politics and 'official' civic politics, the demand for welfare services such as housing, health and education amongst working-class, and particularly women, voters rose significantly. The chief formal conduits for such political dynamics were the political parties, and especially but not exclusively, the still frequently embryonic Labour party. ${ }^{85}$ Yet marked variations existed in different cities between 'expenditure' levels, and either 'need' or 'financial capacity'. Thus, within the spatially specific politics of locality (and setting aside party allegiance), expectation, perception and local enthusiasm — 'the city's intrinsic view of itself' as a whole — remained a key force in setting, driving forward and obtaining policy outcomes. ${ }^{86}$ The local press was central to this latter process: it 'provided its audience with a limited, organized, common frame of reference' - a mediation between the public and private spheres of life - enabling disparate city dwellers to communicate with each other: 'communication in the sense that they could think about the same thing and thus share a vision of social reality. ${ }^{, 87}$

The press seldom constructed this public sphere passively, whether as a partisan or commercial sheet. Indeed in full social reforming mode it could provide a 'showcase for the imagination', juxtaposing signifiers of urban modernity — the expectation — against local, frequently exaggerated, representations of squalor or social regression as 'entertainment', spectacle, and 'thrilling' scenes. ${ }^{88}$ When offering positive constructs of the locale, newspapers and councillors were prone to insular hyperbole: that 'We have the very best (something or other) in the country' ${ }^{89}$ Pejorative stereotypical narrative also had similar attention-seeking functions. Nottingham's press, for example, was not noted for its criticism of local housing policy; generally, it was achievements that dominated 
local constructs in reporting. The Evening Post, nevertheless, happily retold the story of a former London vicar exploring Nottingham's 'appalling' slums: apparently never having 'seen anything quite as bad as what I found here. ${ }^{90}$ In Leicester, shortages rather than dilapidated stock, dominated local disclosure. Yet the methodology functioned similarly, although with greater immediacy because shortages were city wide, not spatially discrete, and were thus less able to be consumed as vicarious pleasures:

The "Mercury" is bringing home to some people the gravity of the housing famine, and thousands of us are hoping the authorities will do something.... Overcrowding is rife. What is more, it exists in some of the better districts with serious results in the way of depreciating the values of the neighbourhood from the health point of view... Can it be wondered at that a certain type of disaffection is bred? It is putting a premium on happy family life which augurs ill for the next generation. $^{91}$

A filtered perception of public opinion in subtle, interactive ways helped continually to determine the local paper's editorial 'line': stereotypically, for example, the passive supposition that its readership supported family and institutional values. ${ }^{92}$

The paper laid claim to articulating a civic concern expressed 'From all quarters of Leicester and from representatives of all classes .... ${ }^{93}$ To do so it utilised a variety of editorial techniques to build a campaign in favour of the 'Boot' concrete house - access, amplification, investigation, analysis and interrogation - which allowed it over time to assert both its own expertise in the matter and its authority and authenticity as a mirror of public opinion. ${ }^{94}$ The latter was constructed consciously around the common-sense of the 'decent-minded citizen'. 95 The paper valorised the establishment of the 'facts' through a spectrum of editorial devices, ranging from anonymous news items and special reports 
by correspondents using first-person narratives, to interviews with the 'houseless' and the presentations of so-called experts. ${ }^{96}$ These were supported by endeavours more transparently driven by opinion, most notably persistent editorialising, but also including the solicitation of support from councillors and others; giving prominence to those in favour of concrete housing (even when they were Tories or Labour), and occasionally inflecting 'straight' reporting with comment. ${ }^{97}$ Finally, the Mercury invited its readership to add its own voice through the letters-to-the-editor column. ${ }^{98}$ 'Seldom has the mind of the public been stirred so greatly as over the question of housing', projected the Mercury, especially when it is women and children that 'Suffer Most'. "II only the Corporation would build some of the concrete house such as you have been advocating", says another of the homeless.' If only it would 'put aside old prejudices and get a move on.' If only, the Mercury complained, it did not have to cite 'Shocking Examples of Overcrowding', of 'People Herded in Rooms Suffering Untold Misery', as it 'brought home to everybody' the 'horror of the housing famine' under headlines of 'Why Houses Must Be Built'! $!^{99}$

That the Mercury sought an alternative 'public legitimacy' did not represent a simple, uni-directional shift of power from local élites to the wider population, facilitated by a newly independent 'free press', however. Such transfers remained heavily circumscribed by persistent social, economic and cultural inequalities which threatened to subvert any agenda for creating a more positive, inclusive and consensual civic-ness. ${ }^{100}$ The Mercury's argument never extended beyond asserting that 'Leicester prides itself upon not being behind the rest of the country where municipal enterprise is concerned'; ${ }^{101}$ and asking, 'When does the Leicester City Council intend to make a 
serious effort to provide houses for the thousands of houseless families?'; 102 'the "Mercury" will continue to concentrate public attention on a crying evil until some more comprehensive scheme is put in hand. ${ }^{103}$ Once these demands had been met, the paper happily acceded to the civic consensus formed around traditional local politics. Its agenda was heavily circumscribed by a sense of renaissance; of putting aside 'past ages' and deploying 'all the skills and experience of the twentieth century' to create 'a new garden city' which would stand as evidence of 'the commercial development of a great city'; of 'the birth of a new town, the physical and moral salvation of 10,000 people, and a vastly important epoch in the history of Leicester ...', epitomised by 'model' and 'picturesque' municipal housing estates. ${ }^{104}$ The paper's chief interest was in the efficacy of using concrete which it did not measure in exclusively material terms, and which afforded ample opportunities for moralising. Of course, it was useful that the housing issue in Leicester crossed party lines; nevertheless, for example, the ways in which organised labour appeared to delay the concrete housing project fused material and moral dimensions. 'We have no longer, it seems, a group of workers in this country who are proud to come to the aid of their distressed fellow-beings,' the paper opined. ${ }^{105}$

The Mercury professed no more than support for a 'progressive housing policy', and its opponents were castigated as 'the kind of people who object to anything new'. ${ }^{106}$ The 'natural' comparison was with nearby Nottingham where civic 'enterprise' had resulted in the building of "“wonder houses"' and claims to have 'led the country' on this issue; ${ }^{107}$ but the paper was moved to report far more widely how 'other towns are in advance of Leicester', even dispatching a 'special correspondent' to several of them, presenting its readers with a comparative view of housing in Birmingham, Sheffield, Belfast, 
Edinburgh, Glasgow, Leeds, Manchester, Liverpool, Derby and even Amsterdam and the USA. ${ }^{108}$ The Mercury only half-heartedly envisaged more popular mobilisation. While it argued in June 1924 that 'protest meetings must be organised' and just over two months later raised the prospect of more protest, nothing of further note materialised. ${ }^{109}$ (Actual physical protest remained a Labour party preserve). Rather, the Mercury encouraged popular expression in more traditional and controlled ways: '... the public, with an eye on future elections, will carefully note the councillors who stand in the way of a progressive housing policy', it warned. ${ }^{110}$ At stake was the construction of a competing 'story'. ${ }^{111}$ The Mercury's version was written in the language of the press and journalism — the rhetoric of 'revelations' and hyperbole which came together in the paper's assertion that it had conducted 'the fullest investigation' into the matter, implying that without this 'spur' there would have been no civic action. ${ }^{112}$ The Mercury was acutely aware of the growing importance of publicity in civic affairs, and of its own specific role. ${ }^{113}$ 'The "Mercury" has hammered away at the problem for months, inspiring several council debates ...', the paper informed its readers; 'the "Mercury" may well claim to have had considerable influence'. ${ }^{114}$ To reinforce the message it published the views of council members who agreed with this perspective. ${ }^{115}$ The key question was who spoke 'on behalf of Leicester'? ${ }^{116}$

The orthodox popularity from which local councils drew their authority — 'the interests of ratepayers' - was no longer of itself sufficient. ${ }^{117}$ The citizenry was constructed as a broader, more inclusive entity — whose identity coincided more closely with the readership of, the letter writers to, and, increasingly if still relatively rarely, those whose stories appeared in the Mercury. ${ }^{118}$ This constituency was translated into an 
'intensity of public feeling' which added considerable 'ginger' to the internal council deliberations 'from outside'. The paper made explicit its view that otherwise councillors would continue 'dilly-dallying' and 'slacking', and while the council was prepared to hide behind 'vague statements', the paper dealt in 'glaring facts' ${ }^{119}$ It was necessary to 'educate the authorities', and to remain vigilant: 'We have effectively learned the lesson that, whatever our smooth speakers have to say on the subject, the price of houses is an eternal worritation'. ${ }^{120}$ The newspaper was an alternative source of information, sanctioned to probe, even to speculate, in order to stimulate, perhaps provoke, official action. ${ }^{121}$ Nevertheless, the Mercury was at pains to stress the non-partisan basis of its actions, and its concern with no more than the 'urgent practical needs of the day' and the requirement for 'business-like speed' in building houses. ${ }^{122}$ The paper was always prepared to work with and through the council, and to ameliorate its criticisms of council members and bodies (although it was also ready publicly to override the internal conventions of the council that diluted direct cross-member criticism). ${ }^{123}$ From the outset, the paper argued that those in housing need were not 'the poorer type of working class' but 'skilled artisans and so-called middle class'; and the issue was not a matter of squalor or poverty but 'sheer overcrowding'. ${ }^{124}$ The question was whether Leicester was prepared to tolerate 'the discomfort, the misery and the danger to health' associated with over-crowding, and which reflected badly on the city as a whole. ${ }^{125}$ Returning more than once to the theme, the paper demanded: 'Where is Leicester's civic pride? ${ }^{126}$ 


\section{Conclusion}

The local press in Britain is commonly discounted as a medium of mass communication, and local evening newspapers in particular have been viewed as primarily commercial ventures peddling an unremitting superficiality supportive of a narrow conservative civic

status quo. ${ }^{127}$ The consolidation of many evening titles into newspaper chains during the 1920s appeared to confirm that they existed chiefly to exploit urban markets for football, racing results, sensation and advertising. Yet these newspapers also adhered editorially to the remnants of an earlier ideal of a 'democracy of print'. Evening newspapers did not merely sell information to cities' inhabitants; they were influential in constructing civic publics. ${ }^{128}$ For their part, readers reciprocated by validating the papers' editorial postures through continued patronage.

In Leicester the Mercury retained a restricted view of the city and its citizens which took for granted the centrality of institutional and family stability, and extended no further than their progressive modernisation — although this in itself was cast as a significant and vibrant step forward. Furthermore, the paper formulated its position in typically journalistic ways through the assertion of 'facts' and the commonsensical, while looking to protect and promote its own self-interests. Its civic vision was comprised of garden suburbs, moral conformity and order as testaments to a thriving city. Insofar as this represented a form of popular mobilisation, it was popular mobilisation on paper only. Nevertheless, the Mercury did offer a rallying-point for the majority of citizens whose access to civic institutions was otherwise curtailed. A confluence of expanding civic responsibilities and growing evening newspaper readerships invited greater public scrutiny of local institutions. Through their support of the paper, ordinary citizens 
licensed it to interrogate, harry and challenge civic authority - and, ultimately, to produce a singularly different version of civic events (although not all radical journalists believed this was enough). ${ }^{129}$

The newspaper discourse of 'civic pride', while still limited, was inherently more inclusive than the deliberations of city councils, and to construct it newspapers had to look beyond the routines of local reporting. They had also to address the tensions that presented themselves between the parochial and wider shared civic experiences, and the primacy of civic leaderships and the expanding impacts of civic activities on ordinary citizens. Local 'licence' came from not only political and economic élites but also from the wider citizenry. The example of the Mercury suggests, however, that in the 1920s the evening newspaper was a significantly more open and dynamic participant in the development of civic democracy than has been hitherto acknowledged.

\footnotetext{
${ }^{1}$ L. Andrews, 'Regional and local newspapers' in R. Bennett-England (ed.) Inside Journalism (London: Peter Owen, 1967), 51.

${ }^{2}$ R. Williams, The Long Revolution (London: Chatto \& Windus, 1961), 199; A. Lee, 'The structure, ownership and control of the press, 1855-1914', in G. Boyce, J. Curran and P. Wingate (eds.), Newspaper History from the Seventeenth Century to the Present Day (London: Constable, 1978), 122.

${ }^{3}$ Andrews, 'Regional', 50-1; R. Williams, 'The press and popular culture: an historical perspective', in Boyce et al, Newspaper History, 50.

${ }^{4}$ R. Williams, Long Revolution, 176.

${ }^{5}$ J. Curran, 'The press as an agency of social control: an historical perspective', in Boyce et al, Newspaper History, 67-75; J. Curran, A. Douglas and G. Whannel, 'The political economy of the human interest story' in A. Smith (ed.), Newspapers and Democracy: International Essays on a Changing Medium (Cambridge, MA: MIT Press, 1980), 288-316.
} 
${ }^{6}$ G. Boyce, 'The Fourth Estate: the reappraisal of a concept', in Boyce et al, Newspaper History, 25, 35-7; C.P. Scott, 'The Manchester Guardian's first hundred years', Manchester Guardian (5 May 1921), repro. in M. Bromley and T. O’Malley (eds.), A Journalism Reader (London: Routledge, 1997), 108-9.

${ }^{7}$ B. Franklin and D. Murphy, 'The local rag in tatters? The decline of Britain's local newspapers', in Bromley et al, A Journalism Reader, 214-28.

${ }^{8}$ J. Stevenson, British Society1914-45, (Harmondsworth: Penguin, 1984), 307-8.

${ }^{9}$ H. Meller, 'Urban renewal and citizenship: the quality of life in British cities, 1890-1990', Urban History, 22 (1995), 65.

${ }^{10}$ P. Thane, The Foundation of the Welfare State (London: Longman, 1982), 196; J. Gyford, S. Leach and C. Game, The Changing Politics of Local Government (London: Unwin Hyman, 1989), 13-15.

${ }^{11}$ Goldsmiths Media Group, 'Media organisations in society: central issues', in J. Curran (ed.), Media Organisations in Society (London: Routledge, 2000), 26-8; D.K. Demers, 'Structural pluralism, corporate newspaper structure, and news source perceptions: another test of editorial vigor hypothesis', Journalism and Mass Communication Quarterly 75, 3 (1998), 572-92.

${ }^{12}$ R. Williams, Long Revolution, 176, 207; C. Seymour-Ure, 'The press and the party system between the wars', in G. Poole and C. Cook (eds.) The Politics of Reappraisal, 1918-1939 (New York: St Martin's Press, 1975), 235-7; Viscount Camrose, British Newspapers and their Controllers (London: Cassell, 1947), $17-19$.

${ }^{13}$ Andrews, 'Regional', 50-1; R. Williams, Long Revolution, 200, 206.

${ }^{14}$ T. Jeffrey and K. McClelland, 'A world fit to live in: the Daily Mail and the middle-classes, 1918-39', in J. Curran, A. Smith and P. Wingate (eds.), Impacts and Influences: Essays on Media Power in the Twentieth Century (London: Methuen, 1987), 31-40. The figures mask considerable local variations: see A. Jones, Press, Politics and Society: A History of Journalism in Wales (Cardiff: University of Wales Press, 1993), 209.

${ }^{15}$ Seymour-Ure, 'Press', 237.

${ }^{16}$ M. Dawson, 'Party politics and the provincial press in early twentieth century Britain: the case of the south west', Twentieth Century British History 9 (1998), 201-18; K. Williams, 'Get Me a Murder a Day!' A History of Mass Communication in Britain (London: Arnold, 1998), 61. 
${ }^{17}$ R. McKibbin, Classes and Cultures: England, 1918-1951 (New York: Oxford UP, 1998), 505; SeymourUre, 'Press', 237; S. Koss, The Rise and Fall of the Political Press in Britain. Vol. 2: The Twentieth Century (London: Hamish Hamilton, 1984).

${ }^{18}$ R. Williams, Long Revolution, 206-8; Seymour-Ure, 'Press', 235.

${ }^{19}$ G. Murdock and P. Golding, 'The structure, ownership and control of the press, 1914-76', in Boyce et al, Newspaper History, 136-7; F. Williams, Dangerous Estate (London: Logmans Green, 1957), 177; Jones, Press, Politics, 203, 209-13.

${ }^{20}$ Seymour-Ure, 'Press', 238.

${ }^{21}$ McKibbin, Classes, 505; R. Williams, Long Revolution, 209.

${ }^{22}$ Curran et al, 'Political economy', 288-316.

${ }^{23}$ H. Hardt, 'The making of the public sphere: class relations and communications in the United States', Electronic Journal of Communication 6,2 (1996) at www.cios.org: accessed 6 October 2000.

${ }^{24}$ Scott, 'Manchester Guardian', 108-9

${ }^{25}$ J. Tunstall, “ "Editorial sovereignty” in the British Press', Studies on the Press (London: HMSO, 1977), 249-341.

${ }^{26}$ Dawson, 'Party politics'; H. Wickham Steed, The Press (Harmondsworth: Penguin, 1938), repro in 'The ideal newspaper' in Bromley et al, A Journalism Reader, 119.

${ }^{27}$ B. Franklin, 'No news is good news: the development of local free newspapers', in B. Franklin and D. Murphy (eds.), Making the Local News (London: Routledge, 1998), 138; B. Franklin and D. Murphy, 'Changing times: local newspapers, technology and markets', in ibid., 14; see also Boyce, 'Fourth Estate'.

${ }^{28}$ M. Schudson, 'The sociology of news production revisited', in J. Curran and M. Gurevitch (eds.), Mass Media and Society (London: Arnold, 1991), 145-6; P. Elliott, 'Professional ideology and organisational change: the journalist since 1800', in Boyce et al, Newspaper History, 183-8; Goldsmiths, 'Media organisations', 26-8; J. H. Weiner, 'The Americanization of the British press, 1830-1914', in M. Harris and T. O’Malley (eds.), Studies in Newspaper and Periodical History: 1994 Annual (Westport, CT:

Greenwood, 1996), 62-5. 
${ }^{29}$ Wickham Steed, 'Ideal'; I. Jackson, The Press and the Local Community (Manchester: Manchester UP, 1971), 8 .

${ }^{30}$ S. Allan, 'News and the public sphere: towards a history of objectivity and impartiality', in Bromley et al, A Journalism Reader, 308-9; Weiner, ‘Americanisation', 65.

${ }^{31}$ A. Smith, 'The long road to objectivity and back again: the kind of truth we get in journalism', in Boyce et al, Newspaper History, 169-70; F. Williams, There is Nothing So Strange as People (London: Cassels, 1970), 49, 53-4.

${ }^{32}$ Weiner, 'Americanisation', 62, 64-5; Williams, Nothing, 50-2.

${ }^{33}$ Curran et al, 'Political economy', 306; M.L. DeFleur, 'Mass communication and social change', in J. Tunstall (ed.) Media Sociology (London, University of Chicago Press 1970), 63-4; T. O’Malley, 'The history of self-regulation', in T. O'Malley and C. Soley, Regulating the Press (London: Pluto, 2000), 29$34,40-44$.

${ }^{34}$ R. Williams, 'Press', 44, 51-2; Boyce, 'Fourth Estate', 20.

${ }^{35}$ R. Williams, Long Revolution, 201-6; Smith, 'Long Road', 168-9.

${ }^{36}$ Jackson, Press, 274-5; N. Drok, Local and regional journalism in Europe (Brussels: European Training Association, 1997), 176-8; H. Cox and D. Morgan, City Politics and the Press (London: Cambridge UP, 1973), 19-20.

${ }^{37}$ H.J. Kleinstuber, 'The global village stays local', in K. Siune and W. Treutzschler (eds.) Dynamics of Media Politics: Broadcasting and Electronic Media in Western Europe (London: Sage, 1992), 144-50.

${ }^{38}$ M. Bromley, 'The end of journalism? Changes in workplace practices in the press and broadcasting in the 1990s', in Bromley et al, A Journalism Reader, 336; Drok, Local and regional, 204; Franklin and Murphy, 'Changing times', 13; D. Simpson, Commercialisation of the Regional Press: The Development of Monopoly, Profit and Control (Aldershot: Averbury, 1981), 200-4.

${ }^{39}$ Camrose, British, 17-19; S. Harrison, 'The local government agenda: news from the town hall', in Franklin and Murphy, Making the Local News, 168; R. Pilling, 'The changing role of the local journalist: from faithful chronicler of the parish pump to multi-skilled compiler of an electronic database', in Franklin and Murphy, Making the News, 183-4.

${ }^{40}$ Boyce, 'Fourth Estate', 20; F. Williams, Nothing, 48. 
${ }^{41}$ Camrose, British, 112-13; I.F. Kernisky, 'Counterpoint: all the information fit to be reported - fabricating American symbolic reality', Electronic Journal of Communication 7,1 (1997) at www.cios.org: accessed 6 October 2000.

${ }^{42}$ B. Harrison, 'Press and pressure groups in modern Britain', in J. Shattock and M. Wolff (eds.), The Victorian Periodical Press: Samplings and Soundings (Leicester: Leicester UP, 1982), 263-5, 299-300. ${ }^{43}$ R. Williams, 'Press', 32.

${ }^{44}$ DeFleur, 'Mass communication', 77-8; R.L. Brown, 'Approaches to the historical development of mass media studies', in Tunstall, Media Sociology, 45-7; D. Caspi, Media Decentralization: The Case of Israel's Local Newspapers (New Brunswick, NJ: Transaction Press, 1986), 71; Cox and Morgan, City Politics, 47-

50.

${ }^{45}$ See Kernisky, 'Counterpoint', and S. Splichal, 'Public opinion as a form of social will: Ferdinand Tönnies’ Critique of Public Opinion', Communications 23, 1 (1998), 101-23.

${ }^{46}$ Boyce, 'Fourth Estate', 28; K. Martin, Father Figures (London: Hutchinson, 1966), 165-70.

${ }^{47}$ R. Williams, 'Press', 49-50.

${ }^{48}$ Leicester Mercury (hereafter LM), 28 September 1925.

${ }^{49}$ LM, 30 September 1925.

${ }^{5050}$ Leicester Records Office, Council Minutes, 29 April 1924; Housing Committee Minutes, 8 March 1926; N. Hayes, 'Civic perceptions: housing and local decision-making in English cities in the 1920s', Urban History 27 (2000), 211-33.

${ }^{51}$ Koss, Rise and Fall, 3, 330-1, 388; Dawson, 'Party Politics'; C. Howard, 'Expectations born to death: local Labour expansion in the 1920s', in J. Winter (ed.), The Working Class in Modern British History: Essays in Honour of Henry Pelling (Cambridge: Cambridge UP, 1983), 65-81.

${ }^{52}$ P. Jones, 'Politics', in D. Nash and D. Reeder (eds.), Leicester in the Twentieth Century (Stroud: Alan Sutton, 1993), 96-100. See, for example, S. Goss, Local Labour and Local Government: A study of changing interests, politics and policy in Southwark, 1919-1982 (Edinburgh: Edinburgh UP, 1988), 18, 2831 , for the anti-socialist 'battle for ideas' fought through the local press. 
${ }^{53}$ In the 1924 municipal elections, of the thirteen contested wards, in seven a Liberal stood against a Conservative, but in 1925 this occurred in only one ward (the remaining ten were straight contests between either Liberal or Conservative and Labour).

${ }^{54}$ LM, 28 May 1924, 25 June 1924; Leicester Mail, 26 May 1924.

${ }^{55}$ D. Fraser, Urban Politics in Victorian England (Leicester: Leicester UP, 1975); K. Young, Local Politics and the Rise of Party (Leicester: Leicester UP, 1975); N. Hayes, Consensus and Controversy: City Politics in Nottingham 1945-1966 (Liverpool: Liverpool UP, 1996).

${ }^{56}$ Leicester Mail, 8 November 1925.

${ }^{57}$ Jackson, The Press, 41-2, 109, 273; and Morgan, City Politics, 108-9.

${ }^{58}$ Pilling, 'Changing role', 188-90.

${ }^{59}$ Jackson, The Press, 21.

${ }^{60}$ M. Bromley, 'Was it the Mirror Wot Won it? The Development of the Tabloid Press During the Second World War', in N. Hayes and J. Hill (eds.), 'Millions Like Us'? British Culture in the Second World War (Liverpool: Liverpool UP, 1999), 93-124.

${ }^{61}$ N. Hayes, 'Civic perceptions', 214-16.

${ }^{62}$ The press had a statutory right to attend council meetings under the Local Authorities (Admission of the Press Act), 1908, which had been quickly passed when the courts ruled that such meeting were private and the public could be excluded.

${ }^{63}$ See, for example, Hayes, Consensus, 117-33; J. Moore, 'Sleaze, Scandals and City Politics: Manchester 1885-1895, ‘Unpublished Paper', Fourth International Conference on Urban History, Venice, 1998.

${ }^{64}$ Lord Snell, 'The Town Council', in H. Laski, W. Jennings and W. Robson (eds.), A Century of Municipal Progress 1835-1935 (London: George Allen and Unwin, 1935), 72.

${ }^{65}$ W. Hampton, Local Government and Urban Politics (Harlow: Longman, $19912^{\text {nd }}$ Edn.), 143.

${ }^{66}$ B. Franklin and D. Murphy, What news? The Market, Politics and the Local Press (London: Routledge, 1991), 58, 74-5.

${ }^{67}$ LM, 5 August 1924.

${ }^{68}$ LM, 3 September 1924, 19 September 1924.

${ }^{69}$ Goss, Local Labour, 27. 
${ }^{70}$ P.R.Shorter, 'Electoral Politics and Political Change in the East Midlands of England 1918-35', (Cambridge Ph.D thesis, 1975), 70. Financially unsuccessful, it was acquired by the Liberal newspaper magnate, Sir Charles Starmer, in 1922.

${ }^{71}$ Nottingham Journal, 3 November 1919.

${ }^{72}$ Nottingham Journal, 2 November 1920, 2 November 1925.

${ }^{73}$ G.R. Searle, The Liberal Party: Triumph and Disintegration, 1886-1929 (Basingstoke: Macmillan, 1992), 152-3.

${ }^{74}$ Jackson, The Press, 42-4; M. Glover, 'Looking at the world through the eyes of ...: reporting the "local" in daily, weekly and Sunday local newspapers', in Franklin and Murphy, Making the Local News, 121; Cox and Morgan, Local Politics, 111-13, 121-2.

${ }^{75}$ Fifth Report from Select Committee on Estimates, PP (1945-6), Mins of Evidence, 173.

${ }^{76}$ Leicester Mail, 22 May 1924; Nottingham Guardian, 5 June 1925, 1 January 1929.

${ }^{77}$ D. Reeder, 'Municipal provision: education, health and housing', in Nash and Reeder, Leicester, 121-39; Hayes, Consensus, 17-28.

${ }^{78}$ Leicester Mail, 1 October 1925; LM, 30 September 1925, 10 November 1925, 6 April 1927.

${ }^{79}$ Consider, as exemplars, the cases of Conservatives Gooding and Thomas (the former praised, the latter pilloried), for their attitudes to housing provision, LM, 28 May 1924 \& 3 Sept. 1924.

${ }^{80}$ B. Anderson, Imagined Communities: Reflections on the Origins and Spread of Nationalism (London: Verso, $19912^{\text {nd }}$ Edn.), 6-7; McKibbin; Classes and Cultures, 505; Jackson, The Press, 273.

${ }^{81}$ Franklin and Murphy, What News?, 56; J. Lawrence, 'The dynamics of urban politics, 1867-1914', in J. Lawrence and M. Taylor (eds.), Party, State and Society: Electoral Behaviour in Britain since 1820 (Aldershot: Scholar, 1997), 84; Glover, 'Looking at the World', 119.

${ }^{82}$ Harrison, 'local government', 157.

${ }^{83}$ H. Laski, 'The Committee System in Local Government', in Laski et al, Municipal Progress, 107; J.D. Marshall, 'Northern Identities', Journal of Local and Regional Studies 20 (2000), 41.

${ }^{84}$ J. Harris, 'Political thought and the Welfare State 1870-1940: an Intellectual Framework for British Social Policy", Past and Present 135 (1992), 116-41. 
${ }^{85}$ M. Savage, 'Urban Politics and the Rise of the Labour Party, 1919-39', in L. Jamieson and H. Corr (eds.), State, Private Life and Political Change (Houndsmill: Macmillan, 1990), 204-23; J. Mark-Lawson, M. Savage, A. Wardle, 'Gender and local politics: struggles over welfare policies, 1918-1939', in The Lancaster Regionalism Group, Localities, class and gender (London: Pion, 1985), 195-215; Howard, 'Expectations'.

${ }^{86}$ M. Powell, 'Did politics matter? Municipal public health expenditure in the 1930s', Urban History 22 (1995), 360-79; Hayes, ‘Civic Perceptions', 233.

${ }^{87}$ D. Nord, 'The Public Community: The Urbanization of Journalism in Chicago', Journal of Urban History 11 (1985), 415.

${ }^{88}$ A. Mayne, The Imagined Slum: Newspaper Representations in Three Cities 1870-1914 (Leicester: Leicester UP, 1993), 22-3, 150-4, 166-75; A. Mayne and Susan Lawrence, 'Ethnographies of place: a new urban history research agenda', Urban History 26 (1999), 325-48. This is not to argue the press consistently supported reform: see, for example, J. Davis, 'The Progressive Council, 1889-1907', in A. Saint (ed.), Politics and the People of London (London: Hambledon: 1989), 27-48.

${ }^{89}$ Leicester Mail, 22 May 1924.

${ }^{90}$ Hayes, 'Civic Perceptions'; Mayne, Imagined Slum, 5-6; Nottingham Evening Post, 8 June 1925.

${ }^{91} L M, 10$ May 1924.

${ }^{92}$ Jackson, Provincial Press, 40.

${ }^{93}$ LM, 10 May 1924.

${ }^{94}$ LM, 23 July 1924, 14 May 1924, 25 November 1925.

${ }^{95}$ LM, 17 May 1924, 21 June 1924.

${ }^{96}$ LM, 1 May 1924, 2 May 1924, 6 May 1924, 5 May 1924, 7 May 1924, 9 May 1924, 13 May 1924, 14 May 1924, 15 May 1924, 19 May 1924, 16 June 1924, 20 January 1925, 10 February 1925, 25 February 1925, 2 June 1926.

${ }^{97}$ LM, 3 May 1924, 6 May 1924, 16 May 1924, 17 May 1924, 24 May 1924, 28 May 1924, 2 June 1924, 7 June 1924, 21 June 1924, 2 July 1924, 16 July 1924, 24 July 1924, 2 September 1924, 3 September 1924, 14 February 1925, 25 November 1925. 
${ }^{98}$ See $L M$,1 May 1924, 5 May 1924, 3 June 1924, 12 July 1924, 24 July 1924, 13 November 1925.

${ }^{99}$ LM, 14 May 1924, 15 May 1924.

100 Goldsmiths, 'Media organisations', 38.

${ }^{101}$ LM, 2 May 1924.

${ }^{102}$ LM, 29 April 1924.

${ }^{103}$ LM, 3 May 1924.

${ }^{104}$ LM, 19 September 1924, 20 September 1924.

${ }^{105}$ LM, 14 February 1925.

${ }^{106} L M, 21$ June 1924, 7 July 1924.

${ }^{107}$ LM, 7 May 1924, 25 February 1925.

${ }^{108}$ LM, 24 April 1924; 29 April 1924; 2 May 1924; 6 May 1924; 7 May 1924; 9 May 1924; 13 May 1924;

19 May 1924; 20 May 1924; 28 May 1924; 4 June 1924; 8 July 1924, 10 November 1925.

${ }^{109}$ LM, 25 June 1924, 4 September 1924.

${ }^{110}$ LM, 7 July 1924.

${ }^{111} L M, 19$ September 1924.

${ }^{112}$ LM, 3 May 1924, 15 May, 1924, 17 May 1924, 28 May 1924, 21 June 1924, 8 July 1924

${ }^{113}$ LM 17 May 1924, 21 June 1924.

${ }^{114}$ LM, 24 July 1924,19 September 1924.

${ }^{115}$ LM, 25 June 1924, 12 July 1924.

${ }^{116}$ LM, 25 June 1924.

${ }^{117}$ LM, 30 April 1924, 2 September 1924.

${ }^{118}$ LM, 1 May 1924, 3 May 1924, 25 Nov 1925.

${ }^{119}$ LM, 24 May 1924, 25 June 1924, 9 July 1924, 25 November 1925.

${ }^{120}$ LM, 21 June 1924, 9 July 1924.

${ }^{121} L M, 30$ September 1925.

${ }^{122}$ LM, 25 June 1924, 2 September 1924.

${ }^{123}$ LM, 3 September 1924, 19 September 1924; Hayes, 'Civic perceptions', p. 221.

${ }^{124}$ LM, 7 May 1924, 13 May 1924. 
${ }^{125}$ LM, 5 May 1924, 12 July 1924.

${ }^{126} L M, 3$ September 1925.

${ }^{127}$ Franklin and Murphy, 'The local rag'; Murphy, 'Control without censorship', in J. Curran (ed.), The British Press: A Manifesto (London; Macmillan, 1978), 187.

${ }^{128}$ See. J. Hartley, Popular Reality: Journalism, Modernity, Popular Culture (London: Edward Arnold, 1996), 47.

${ }^{129}$ See F. Williams, Nothing, 45-7. 